\title{
Comparison of mass balances for Vernagtferner, Oetzal Alps, as obtained from direct measurements and distributed modeling
}

\author{
Frank PAUL, ${ }^{1}$ Heidi ESCHER-VETTER, ${ }^{2}$ Horst MACHGUTH ${ }^{1}$ \\ ${ }^{1}$ Department of Geography, University of Zürich-Irchel, Winterthurerstrasse 190, CH-8057 Zürich, Switzerland \\ E-mail: frank.paul@geo.uzh.ch \\ ${ }^{2}$ Commission for Glaciology, Bavarian Academy of Sciences and Humanities, Alfons-Goppel-Strasse 11, \\ D-80539 Munich, Germany
}

\begin{abstract}
The direct comparison of modeled glacier mass-balance distribution with field measurements could be problematic, as the methodology of determination and the processes considered at the point or catchment scale could differ strongly. Moreover, direct measurements cover only small parts of a glacier, and model performance is thus difficult to assess outside these regions. Remaining opportunities for model validation include comparison of snowlines, as derived from remote-sensing data, and maps of the mass-balance distribution, as interpreted by observers with local knowledge. This study compares such hand-drawn maps of the Vernagtferner (Oetzal Alps) mass balance with the modeled pattern as obtained from a distributed energy-/mass-balance model of intermediate complexity. The model is driven by measured daily values of temperature, global radiation and precipitation from a nearby climate station and grids of mean daily potential global radiation and climatologic annual precipitation sums. Compared with the direct measurements, the calculated mean mass balance and equilibrium-line altitude agreed very well in both balance years, although the spatial pattern of the mass-balance distribution displayed larger deviations in regions influenced by snowdrift or local topographic undulations. However, compared with the remaining snow as visible on a satellite image from 1999, the modeled snowline pattern for a larger sample of glaciers is in very good agreement.
\end{abstract}

\section{INTRODUCTION}

Distributed glacier mass-balance models have become a common tool in the calculation of a glacier's mass balance or its change due to a change in climate. Here, we focus on models that calculate the energy balance at the glacier surface, because these can be applied over larger regions without local tuning and have a higher flexibility with the input parameters to be included. In principle, three main problems are associated with such large-area applications: (1) the required meteorological input data; (2) the spatial extrapolation or interpolation of these data in complex topography; and (3) model validation. Several studies have calibrated and validated model results with measured runoff (e.g. Escher-Vetter, 1985; Hock and Holmgren, 2005) or point-specific results at ablation stakes (e.g. Arnold and others, 1996; Brock and others, 2000; Klok and Oerlemans, 2002; Reijmer and Hock, 2008). However, studies that compare model results with measured mass balances as obtained in the field by traditional methods over an entire balance year are more rare (e.g. Gerbaux and others, 2005; Schuler and others, 2005; Machguth and others, 2006a). From the perspective of operational glacier monitoring, and to reduce the method-dependent variability, it would be desirable to use the same method to recalculate mass balance over the entire surface of all glaciers in the network. In principle, a distributed mass-balance model can do this (Huss and others, 2008); however, the obtained mass balances must be considered to be no longer independent of climate data. Furthermore, local processes (e.g. snow redistribution, debris cover) should be considered in the model when they are important for the respective glaciers.

A direct comparison of measured and modeled mass balance is difficult, as the interpolation techniques could be completely different. Field measurements might be interpolated to the entire glacier surface by a polynomial regression or kriging techniques (e.g. Hock and Jensen, 1999), whereas a model calculates mass balance for individual gridcells from a digital elevation model (DEM) and zonal averaging (e.g. Machguth and others, 2006a). Moreover, the processes considered during the careful interpretation of the field data using local knowledge are not the same as those used by a model that accounts for topographic effects such as shading from a DEM (e.g. Klok and Oerlemans, 2002). A comparison with model results could reveal that the values measured at point locations are not representative of the mass balance of an elevation band (Arnold and others, 2006). Compared with mass-balance profiles derived from a regression, the results from distributed models have a higher variability with elevation, and might thus yield different mass-balance gradients (Machguth and others, 2006a). As a result of the rapidly changing glacier geometries in the last two decades (e.g. disintegration of Careser glacier, Italy (Carturan and Seppi, 2007; Paul and others, 2007)), formerly established regressions for mass-balance determination might be less valid today. Moreover, in the last two decades, many glaciers in the Alps have been completely free of snow during or at the end of the ablation period, and some have even lost all firn reserves. The related changes in albedo have considerable influence on the melt rates and could substantially modify mass-balance profiles, with increasing ablation towards higher elevations (Paul and others, 2005).

Such new conditions might be better captured by a distributed model than by the currently applied extrapolation of measurements, as melt of snow and ice could be modeled very accurately (e.g. Hock, 2005). However, processes related to accumulation (e.g. wind redistribution 


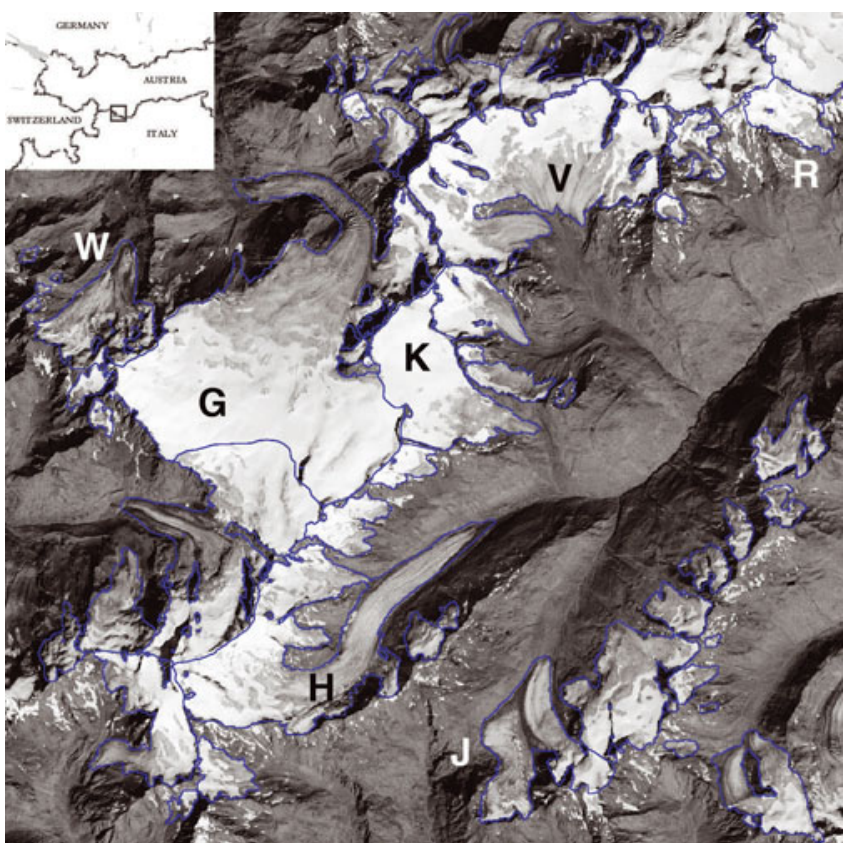

Fig. 1. Location of the test site in the Alps (inset) and model domain of this study in the southern Oetztal Alps as seen on a Landsat Thematic Mapper panchromatic image from 13 September 1999. Letters on the image denote glacier names: G, Gepatschferner; $\mathrm{H}$, Hintereisferner; J, Hochjochferner; K, Kesselwandferner; R, Rofenkarferner; V, Vernagtferner; W, Weißseeferner.

of snow) are still less well understood and are subject to ongoing research (Bernhardt and others, in press). Accordingly, accumulation is only roughly parameterized in current models, or is used as a tuning factor to fit measurements at specific sites (e.g. Klok and Oerlemans, 2002). Nevertheless, as annual balance for glaciers in the Alps is determined largely by the summer balance, a good agreement between measured and modeled mass balance is obtained in most of these studies. In this investigation, we also compare annual mass balances, but for the entire glacier surface and on a glacier (Vernagtferner, Oetzal Alps, Austria) on which wind redistribution of snow has a marked influence on the annual mass-balance pattern (Plattner and others, 2006).

To assess model performance in regions that are not covered by direct measurements, we here compare the pattern of the modeled mass-balance distribution with maps that are based on human interpretation and local expert knowledge. This allows us to reveal shortcomings of the used input data and the processes considered by the model, but precludes a site-specific tuning. Previous studies related to the comparison for an entire glacier have compared model results with observed snowline retreat for Storglaciären, Sweden (Hock and Holmgren, 2005) and observed patterns of ice, firn and snow distribution on Vernagtferner (EscherVetter, 2000). Both studies yield a fairly good agreement between modeled and observed patterns, but only the melt period was considered. In this study, we calculate mass balance over an entire balance year and cover a larger region of the southern Oetztal Alps at the same time, including the glaciers Hintereis-, Kesselwand- and Vernagtferner. Also for this reason, we run the model without local tuning, as this could degrade model performance for neighboring glaciers (Paul and others, 2008). The applied corrections for some parameters are based on independent studies or previously used typical values from the literature.

\section{TEST SITE AND INPUT DATA}

\section{Study region}

The test site, located in the southern Oetztal Alps (Fig. 1), is $17 \mathrm{~km}$ by $15 \mathrm{~km}$ in area (centered at $46.8^{\circ} \mathrm{N}, 10.83^{\circ} \mathrm{E}$ ), and includes three glaciers with long-term mass-balance measurements: Vernagt-, Kesselwand- and Hintereisferner (measurement started in 1965, 1953 and 1953, respectively). The region is somewhat shaded from precipitation, and climate conditions are thus more continental than in most other parts of the Alps. According to the precipitation map from Schwarb and others (2001), an annual amount of $1 \mathrm{~m}$ is found at $2600 \mathrm{~m}$ a.s.I. in the Vernagtferner catchment (mean value for the 1971-90 period). In this respect, the steady-state equilibrium-line altitudes $\left(E A_{0}\right)$ are comparably high: 2980-3120 ma.s.l. for the three above-mentioned glaciers (Haeberli and others, 2001). Although the focus here is on the mass-balance distribution of Vernagtferner $\left(8.5 \mathrm{~km}^{2}\right.$, 2765-3627 ma.s.l.), the results obtained for the other two glaciers and the entire study region are also analyzed.

The mass balance is calculated for the 1997/98 and 1998/ 99 balance years because they were rather different (strongly negative and close to zero, respectively) and because glacier outlines and a DEM from 1999 are available for the model domain. The mass balance is measured using the fixed-date system (1 October to 30 September) and the same time period is used for the modeling in both years. The meteorological variables are measured near the gauging station Vernagtbach (2640 ma.s.l.), which is about $1 \mathrm{~km}$ downstream from the terminus of the glacier. Most parts of Vernagtferner face to the east, south, or southwest (Fig. 1), and topographic shading plays only a minor role during summer (Reinwarth and Escher-Vetter, 1999).

\section{Topography and glacier outlines}

The topography of the model domain is given by a DEM with $25 \mathrm{~m}$ grid spacing $(680 \times 600$ cells $)$ from swisstopo that has been interpolated from contour lines of a 1:50000 map compiled in about 1985. As most glaciers have decreased strongly in elevation since 1985 (in particular near the terminus), elevations have been updated with the SRTM3 (Shuttle Radar Topography Mission 3) DEM from 1999 (e.g. Farr and others, 2007). In the case of a lowered glacier surface, the elevations inside the 1985 glacier extent are replaced in the DEM with values from 1999. Glacier outlines from 1985 and 1999 have been derived automatically from multispectral classification of Landsat satellite data, with manual corrections in a few regions with thick debris cover (Paul, 2002). The derived outlines from 1999 for Vernagtferner agree very well with those used to calculate the mass balance (Kommission für Glaziologie, 2001). Moreover, the area-elevation distribution of the glacier from the updated DEM is (except for a slightly larger region between 3400 and $3500 \mathrm{~m}$ ) nearly identical with that used for the field measurements. For comparison with the modeled snowline, the study region is illustrated in Figure 1 with the panchromatic band from the Landsat scene acquired on 13 September 1999.

\section{Daily meteorological variables}

The model is forced with daily means of temperature $(T)$ and global radiation $(R)$, and with daily sums of precipitation $(P)$ as measured near the gauging station Vernagtbach. The time series of all three parameters are shown in Figure 2. In the 

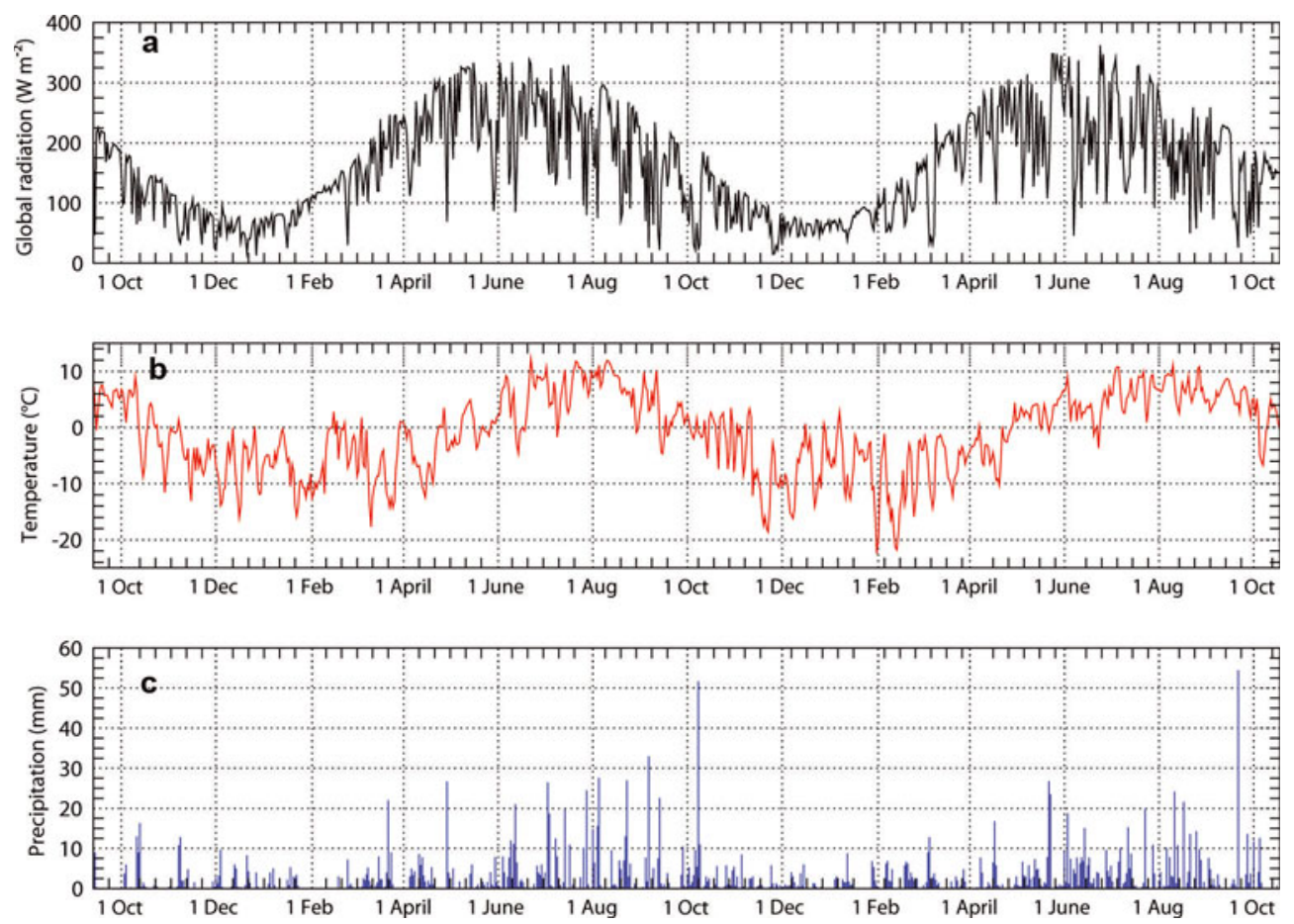

Fig. 2. Time series of measured mean daily global radiation (a), temperature (b) and precipitation sums (c) for the balance years $1997 / 98$ and 1998/99. All values are original data from the climate station at the Vernagtbach gauging station (2640 m a.s.l.).

case of $T$ and $R$ they were aggregated from hourly mean values as stored by a Modas data logger with a scan rate of $2 \mathrm{~s}$. The daily sums of $P$ are obtained from paper charts with monthly records derived from a Belfort weighing rain gauge. Although this tool provides reliable precipitation amounts in summer, the data acquisition in winter is, in part, questionable, due to burying under the snow, wind drift into and out of the gauge, and the possible malfunction of the device during unattended operation. The measured day-to-day variability of pressure and relative humidity was not included in the calculation of the energy balance, as the variability has only a limited influence on the mass balance (Oerlemans, 2001). However, we used the measured annual mean values as a base for calculating their elevation and temperature-dependent variability. Wind speed and direction were also measured, but were not used in this study because the calculation of the turbulent heat fluxes does not include wind speed; snow redistribution by wind was also not considered.

\section{Meteorological variables in a grid format}

The spatial distribution of $T, P$ and $R$ as measured near the run-off gauge follows three different approaches (Paul and others, 2008): Temperature depends on elevation only and is calculated for each DEM cell from the measured value $T$ and a standard atmospheric lapse rate of $-0.0065^{\circ} \mathrm{Cm}^{-1}$. We acknowledge that the lapse rate is not constant during a year (often much lower in winter), but for the calculation of glacier mass balance in this climatic zone the summer lapse rate is more important. Precipitation for each gridcell is obtained by multiplying the measured daily sum $P$ with a resampled and normalized grid from the Schwarb and others (2001) climatology. The resampling from the original $2 \mathrm{~km}$ resolution to the $25 \mathrm{~m}$ cells of the DEM uses bilinear interpolation. The normalization procedure divides all values of the climatology by the annual sum at the location of the gauging station $(1040 \mathrm{~mm})$. The measured annual sums at the gauging station $(876 \mathrm{~mm}$ in 1997/98 and $989 \mathrm{~mm}$ in 1998/99) are $5-15 \%$ smaller than in the climatology. To account for the systematic undercatch by precipitation gauges of solid precipitation, all gridcells are multiplied by a factor of 1.2 (a 20\% increase), as recommended by Frei and Schär (1998). The precipitation distribution before normalization is illustrated in Figure 3a. Apart from a general increase in precipitation with elevation, several local deviations of this rule are visible. These reflect the influence of the topography considered during the interpolation of the Schwarb and others (2001) dataset. The range of annual precipitation sums over glaciers varies between 910 and $1270 \mathrm{~mm}$.

The mean daily potential (clear-sky) global radiation is calculated beforehand for each day of the year and for each cell of the DEM by the solar radiation model SRAD (Wilson and Gallant, 2000). SRAD fully accounts for all topographic effects (e.g. slope, aspect, shading, sky-view factor) and is of a higher quality than other models (Heggem and others, 2001). Set against the measured global radiation $R$, the values from SRAD form an envelope enclosing the measured maximum values. The measured mean daily global radiation $R$ is then used to calculate a mean daily cloud factor ( $R$ divided by the potential radiation), which is used for the entire model domain. Figure $3 \mathrm{~b}$ shows the modeled global radiation at Julian day 212 (1 August). High amounts of global radiation are received on flat surfaces, more or less independent of their aspect (the steeper the slope the more important the aspect becomes). In a high-mountain environment, such flat regions are found in the accumulation areas of glaciers. Hence, mass-balance profiles might be subject to large changes as soon as the snow in the accumulation region of these glaciers is replaced by (much darker) firn or bare ice (Paul and others, 2005). 

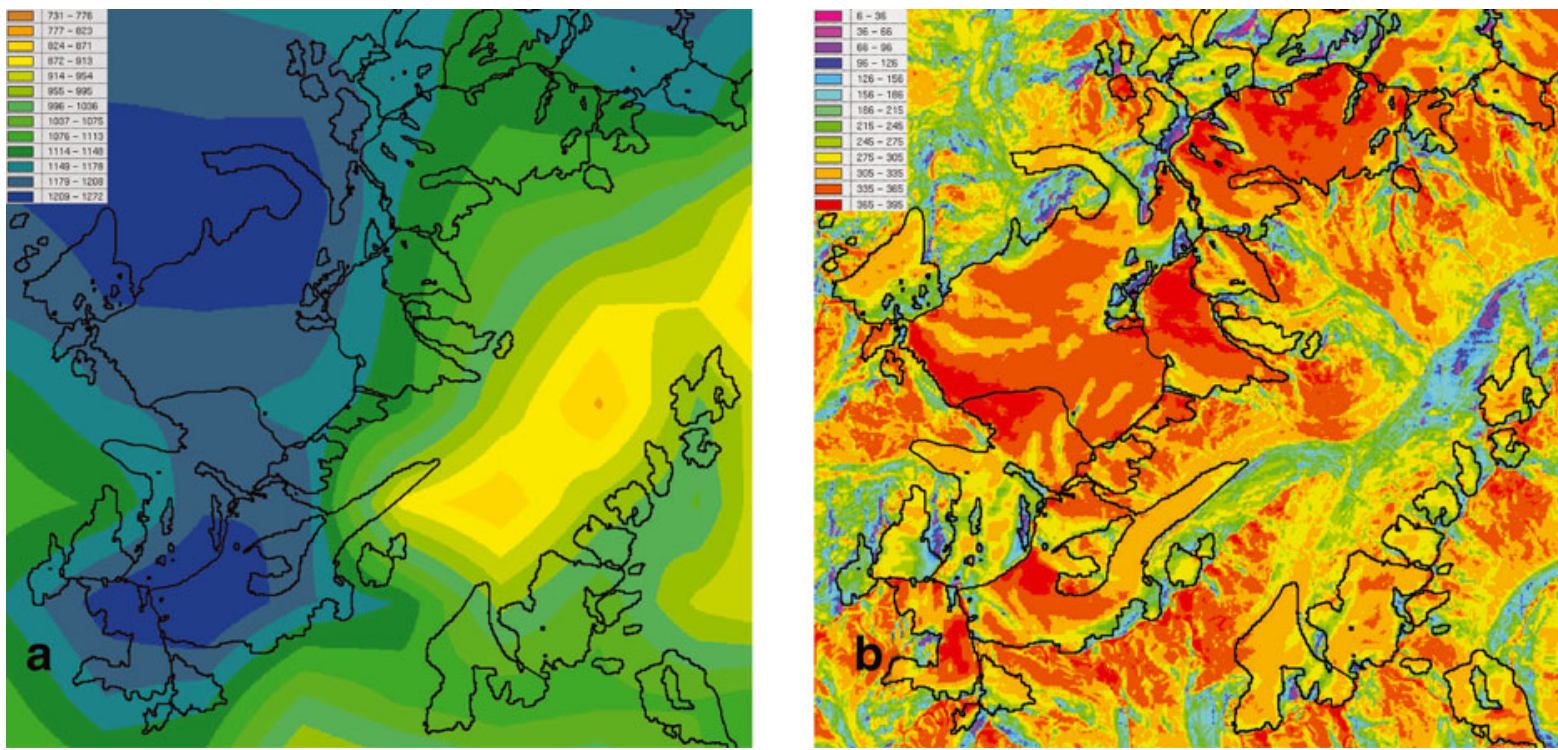

Fig. 3. Examples of grid input datasets as applied to the entire model domain. Black lines indicate glacier extent in 1999 as derived from a Landsat Thematic Mapper scene. (a) Spatial distribution of the mean climatologic (1971-90) annual precipitation sum from Schwarb and others (2001) after bilinear interpolation to $25 \mathrm{~m}$. (b) Mean potential global radiation for Julian day 212 (1 August) as modeled with the SRAD code. In part, the DEM25 from swisstopo has been used for the modeling.

\section{METHODS}

\section{The distributed glacier mass-balance model}

The mass-balance model is based on the assumption that the most important variables (potential global radiation, temperature, precipitation) are determined accurately whereas others are treated more roughly or kept constant at their climatologic or measured mean values for the respective year. In general, this approach leads to very good results, as much of the mass-balance variability is determined by these three variables (Oerlemans, 2001; Hock, 2005). Melt of snow or ice occurs in the model when the energy balance is positive; a possible ground-heat flux and the energy provided by refreezing of water are neglected in the model. The model run started at Julian day 270 (29 September) of the respective year with a snow-free surface (using the ice albedo throughout) and calculates mass balance for each cell of the DEM at daily steps until day 269 in the following year. More details of the modeling approach are described by Paul and others (2008). The model was validated with ablation stake measurements and compared with the mass balance profiles of two glaciers in the Swiss Alps; this comparison indicated an encouraging agreement (Machguth and others, 2006a). The physics of the model is to a large extent based on the parameterizations given by Klok and Oerlemans (2002), and we thus focus here on the description of the applied modifications and selected parameters.

Our version of the model has been adapted to run with a priori calculated grid datasets (e.g. mean daily potential global radiation) and is less complex because it uses daily time-steps. The two most important differences between the model physics and the Klok and Oerlemans (2002) model are: (1) a single surface layer with a constant $0^{\circ}$ temperature for the entire glacier throughout the year; and (2) a less complex calculation of the turbulent fluxes, which is adapted from Oerlemans (1992). The single surface layer precludes consideration of the penetration of a winter cold wave into the snowpack. This results in an earlier meltout of the bare ice by a few days, but has little impact on the annual mass balance (Greuell and Oerlemans, 1986). The use of a $0^{\circ} \mathrm{C}$ surface temperature resulted in a much higher emission of longwave radiation during winter, but this had no impact on the modeled mass balance because the energy balance remains negative during winter (Oerlemans, 1992). The bulk approach used to calculate the turbulent fluxes lumps wind speed into the exchange coefficient but allows the latter to vary with distance from the ELA, so as to consider increased surface roughness down the glacier (Oerlemans, 1992). In our opinion, this is a viable approach of calculating turbulent fluxes over entire glaciers from meteorological data measured at some distance from the glacier.

Fixed values have been used for cloud height $(5000 \mathrm{~m})$, snowfall threshold temperature $\left(1.5^{\circ} \mathrm{C}\right)$, bare-ice albedo (0.3) and fresh-snow albedo (0.8). They reflect mean values from a larger possible range and are based on commonly used values and experience of the authors. Slightly different parameterizations are used for the calculation of cloud cover (following Oerlemans, 1991) and atmospheric pressure (adapted from Mittaz and others, 2002). The reduction of snow albedo by metamorphosis is included with an exponential aging function linked to the number of days since the last snowfall ( $>1 \mathrm{~mm}$ w.e.) and whether temperature at the DEM cell is above or below $0^{\circ} \mathrm{C}$ (ECMWF, 2004). This resulted in variations of the snow albedo of 0.7-0.8 during winter. In the model, snow thickness is in $\mathrm{mm}$ w.e. and liquid precipitation does not contribute to mass balance.

\section{Observed mass-balance distribution}

The mass balance for Vernagtferner is determined in the field with the direct glaciological method (Kaser and others, 2003). The areal distribution of specific net mass-balance values is derived from stake and pit measurements at about 
a

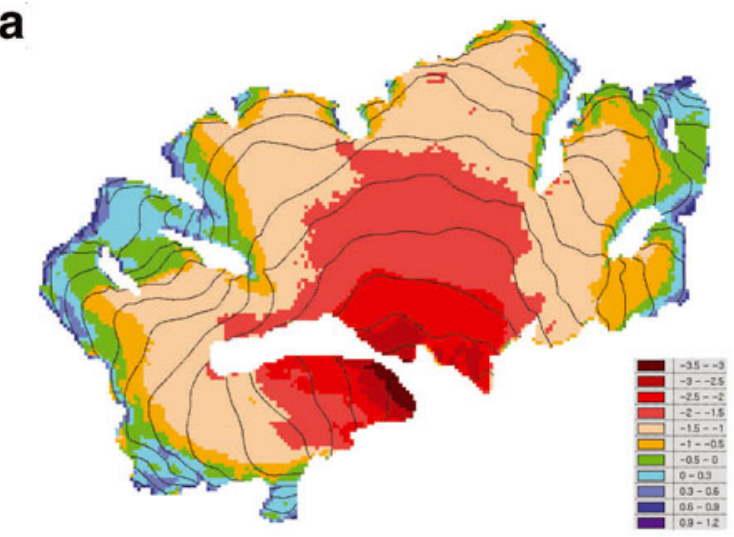

C

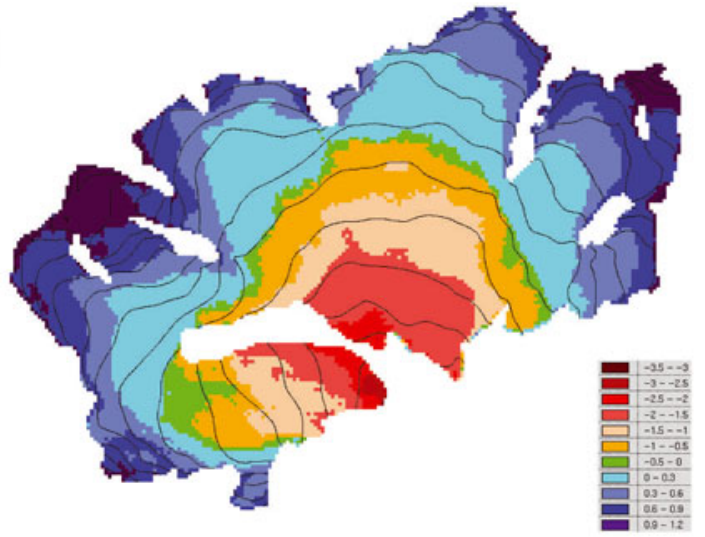

b

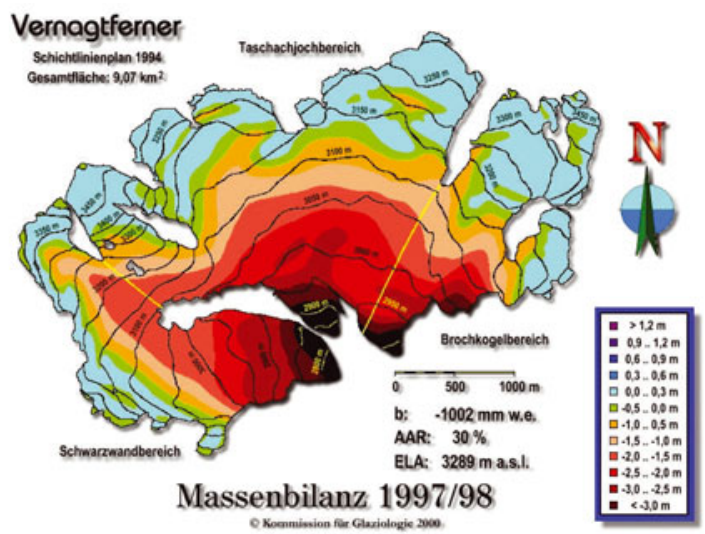

d

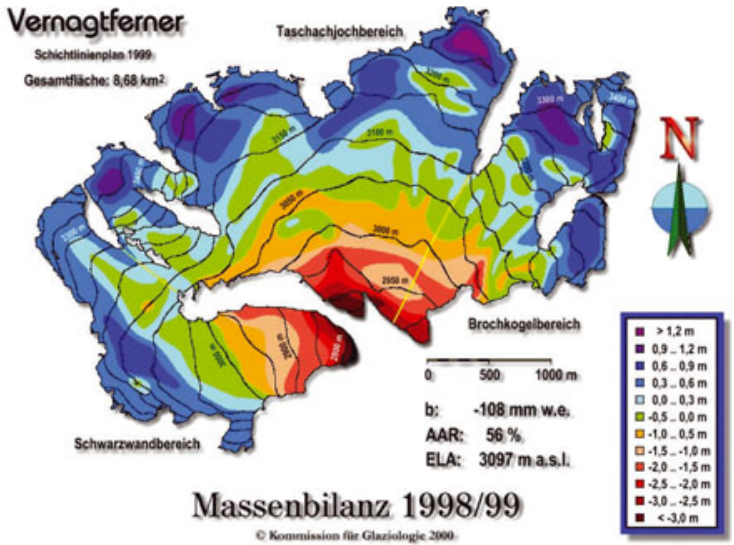

Fig. 4. Comparison of modeled ( $a, c)$ and measured $(b, d)$ mass-balance distribution for Vernagtferner in the balance years $1997 / 98$ (a, b) and 1998/99 (c, d). The same colour legend is used for all images.

50 sites, with most of the stakes placed in the lower part of the ablation area (WGMS, 2001). On the basis of the readings at the end of the glaciological year, the specific accumulation and ablation values at the sites are mapped, and isolines of specific water balance are drawn and integrated over $50 \mathrm{~m}$ contour intervals. Reinwarth and Escher-Vetter (1999) give an example for 1978/79, a year with a near-zero mass balance for the entire glacier. As explained before, the mass balance as measured at the ablation stakes is not used for a direct comparison with the model results. Instead, the mass-balance distribution as reported in the maps of WGMS (2001) is used for better visibility in the colour-coded version as prepared for the internet (www.glaziolgie.de).

\section{GIS-based calculations}

A Geographic Information System (GIS) allows us to perform (statistical) calculations over large samples of number-coded entities like glaciers. The basic idea is to assign to each glacier a unique code representing a zone and to calculate statistical data for a 'value' grid (e.g. a DEM or the modeled mass balance) for each of the zones. In this way, mean mass balance is calculated for each of the selected glaciers. This implies that $B_{\text {a }}$ (total annual balance) and $S$ (total surface area) are not calculated explicitly for each elevation band, but only $B_{\mathrm{a}} / S$ or $b_{\mathrm{a}}$ (specific annual balance). As the hypsography for Vernagtferner from the updated 1999 DEM is nearly identical with that used for extrapolation of the field measurements, there are only small differences of the mean mass balance due to this deviation. In this study, the GIS is used for: colour-coding the modeled mass-balance values as used for the maps of the measurements,

calculating mean mass-balance values for selected glaciers of the model domain, and

determining mean mass balance in $50 \mathrm{~m}$ elevation bands for the comparison of profiles.

\section{RESULTS}

\section{Mass balance of Vernagtferner}

The spatial distribution of the mass balance from the model and as measured in the field for the two balance years is depicted in Figure $4 \mathrm{a}-\mathrm{d}$. The colours used for the respective value ranges are about the same. The related mass-balance profiles are given in Figure 5. In the 1997/98 balance year, the modeled mass-balance distribution (Fig. 4a) shows an underestimation of mass loss near the terminus and an overestimation in the higher regions, in particular for the middle and eastern sections of the glacier. In the upper part of the western section, there is even a more positive balance than in the field interpretation (Fig. 4b). Integrated over the entire glacier, the mass-balance profile reveals this elevationdependent under- and overestimation clearly (Fig. 5). Both deviations together average out and the modeled mean mass balance $(-1.06 \mathrm{~m})$ is nearly identical to the fieldderived value $(-1.0 \mathrm{~m})$. For the small north-facing part of the western tongue ('Schwarzwandbereich') there is also a reasonable agreement with the field-derived values, and in particular the pattern. The ELA correctly crosses an altitude 


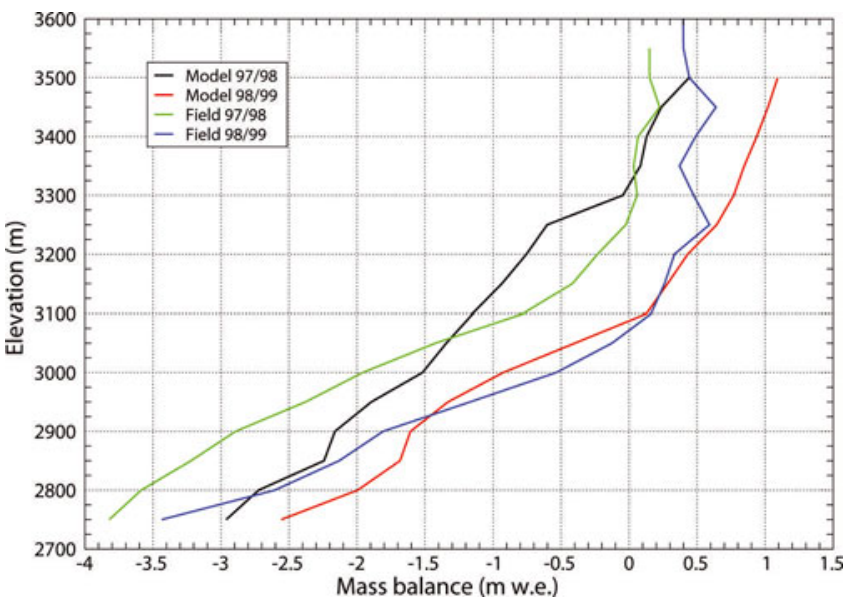

Fig. 5. Modeled and measured mass-balance profiles in the two balance years for Vernagtferner.

range of about $400 \mathrm{~m}$ on the glacier, and the pattern around the three rock outcrops at the western side is also modeled correctly. Most obvious is the much more negative modeled mass balance for the region south of 'Taschachjochbereich'.

For the more positive balance year 1998/99, the overall agreement of the modeled (Fig. 4c) and the measured pattern (Fig. 4d) is much better. Again, the mass balance is more positive in the model near the glacier terminus. However, this time it is also more positive than measured at higher elevations for the Schwarzwand tongue and only slightly more negative for the other glacier parts. Although the model does not capture the high variability of the mass balance near the ELA (between green and cyan), the mean position of the ELA (visually averaged) is modeled very well. The good agreement is also reflected in the mass-balance profiles (Fig. 5), a nearly identical position of the ELA when averaged over the entire glacier (about $15 \mathrm{~m}$ higher in the model) and a nearly identical mean mass balance $(-0.09$ instead of $-0.11 \mathrm{~m}$ w.e.).

The comparison of the mass-balance profiles (Fig. 5) reveals some further points. In general, the mass-balance gradient for 1998/99 agrees much better with the measured gradient, in particular in the ablation region. In the $1997 / 98$ balance year the modeled gradient is considerably smaller than the measured gradient $(-0.6$ instead of $-1 \mathrm{~m}$ w.e. $(100 \mathrm{~m})^{-1}$. This implies that balance gradients (in the ablation area) are modeled better when the mean balance is close to equilibrium. Although accumulation is overestimated in the 1998/99 balance year above $3250 \mathrm{~m}$, the absolute values agree fairly well in 1997/98. The overestimation in 1998/99 suggests processes of snow removal from steep slopes (Gruber, 2007) that are not considered in this model. In both cases, the mass balance is about $0.8 \mathrm{~m}$ w.e. more positive at the lowest elevations in the model. This is most likely due to a considerably lower albedo in this region than used in the model.

\section{Mass balance in the entire study region}

Figure $6 a$ and $b$ show the mass-balance distribution for the two balance years and the entire study site, using the same colour table as in Figure 4. At first glance, it seems that the model is also able to calculate realistic mass-balance distributions for the other glaciers. When considering the measured mass balance at Hintereis- and Kesselwandferner (Table 1), a very good agreement with the model result for Hintereisferner in 1997/98 and for Kesselwandferner in $1998 / 99$ is found. In the other years, the mass balance is $0.3 \mathrm{~m}$ w.e. too positive for Kesselwandferner and $0.4 \mathrm{~m}$ w.e. too negative for Hintereisferner (Table 1). This has two implications: (1) model tuning in any direction is rendered useless because it degrades the result for the other glacier at the same time; and (2) the reasons for the deviations are different in both cases.

Most remarkable is the more negative mass balance at the terminus of Gepatsch- and Hintereisferner (' $\mathrm{G}$ ' and ' $\mathrm{H}$ ' in Fig. 1) in the more positive balance year 1998/99. This phenomenon could be observed in the modeled massbalance distribution for elevations below $2300 \mathrm{~m}$ a.s.l. With regard to the differences in the accumulation area when comparing the two mass-balance years, there is a large variability from glacier to glacier. Whereas a few glaciers increased their snow-covered region only slightly from $1997 / 98$ to $1998 / 99$ (e.g. Weißseeferner 'W' or Hochjochferner ' $\mathrm{J}$ ' in Fig. 1), others changed more significantly (e.g. Gepatschferner ' $\mathrm{G}$ ' or Vernagtferner ' $\mathrm{V}$ ' in Fig. 1), or even became more or less completely snow-covered (e.g. Kesselwandferner ' $K$ ' or Rofenkarferner ' $R$ ' in Fig. 1). This indicates that the mass-balance sensitivity of the latter glaciers is higher than that of the other glaciers. Indeed, Kesselwand- and Rofenkarferner advanced strongly in the 1970s and 1980s (Kuhn and others, 1985).

Compared with the satellite image from 13 September 1999 (Fig. 1), the modeled snow-covered regions (with a mass balance $>0$ ) for the 1998/99 balance year (Fig. 6b) are in close agreement for nearly all glaciers, including many of the smaller ones, and partly also when considering subtle details. When reference is made to the modeled spatial pattern instead of the absolute values, the agreement further improves. Local deviations could often be explained by snow avalanching from steep slopes, which is not considered in this model but could be an important source of accumulation or ablation for small glaciers (Kuhn, 1995).

Table 1. Comparison of modeled and measured mass balance (in m w.e.) for three glaciers in the Ötztal Alps in the two balance years

\begin{tabular}{lcccrrrrrr}
\hline & \multicolumn{3}{c}{ Vernagtferner } & \multicolumn{3}{c}{ Kesselwandferner } & \multicolumn{3}{c}{ Hintereisferner } \\
Year & Model & Field & Difference & Model & Field & Difference & Model & Field & Difference \\
\hline $1997 / 98$ & -1.06 & -1.0 & -0.06 & -1.03 & -0.60 & -0.43 & -1.21 & -1.23 & +0.02 \\
$1998 / 99$ & -0.09 & -0.11 & +0.02 & +0.02 & -0.01 & +0.03 & -0.56 & -0.86 & -0.30 \\
Range & 0.97 & 0.89 & +0.08 & 1.05 & 0.61 & +0.44 & 0.65 & 0.37 & +0.28 \\
\hline
\end{tabular}



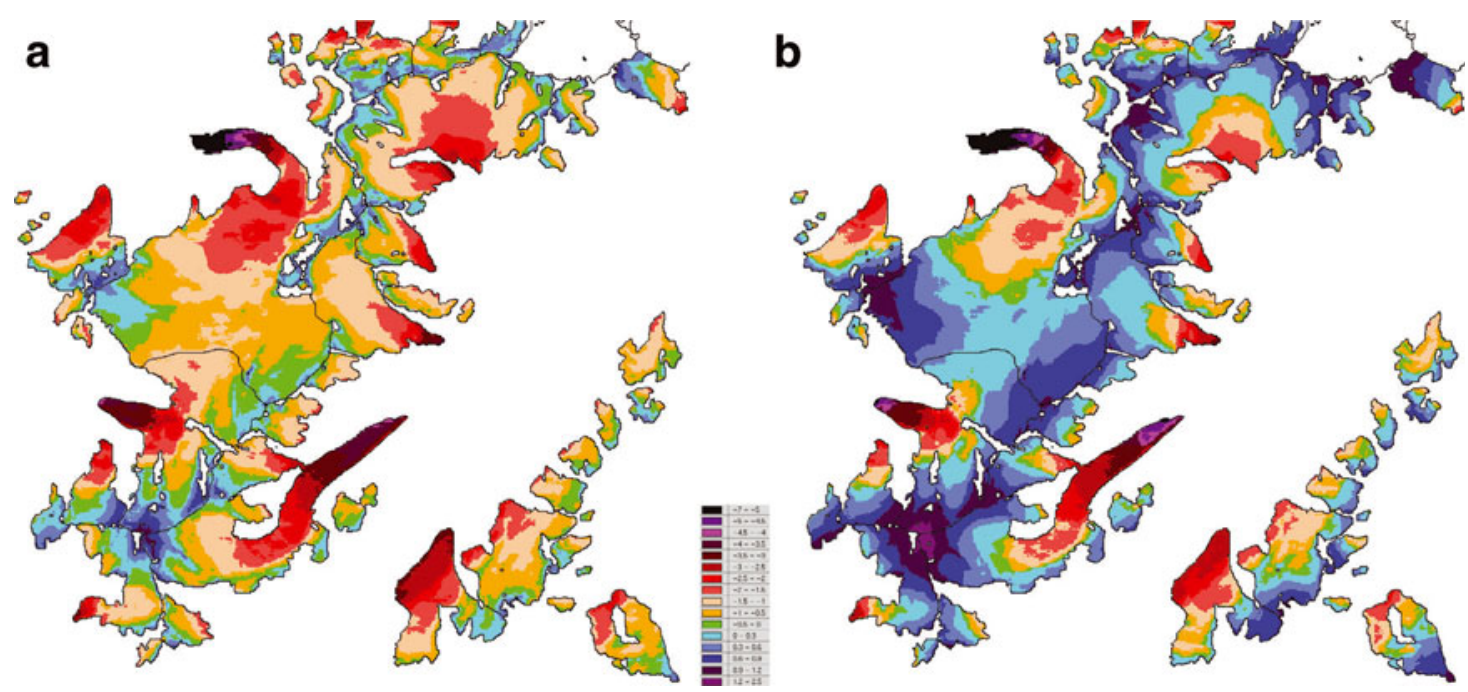

Fig. 6. Mass-balance distribution as modeled for the entire study region in the years (a) 1997/98 and (b) 1998/99.

\section{DISCUSSION}

\section{Meteorological parameters}

The differences of the climatic conditions in the two balance years should be able to explain a large part of the contrasting mass-balance conditions in both years. Whereas the sum of the measured (uncorrected) winter (November to March) precipitation is nearly identical in both years (204 and $211 \mathrm{~mm}$, respectively), the mean values of summer (June to August) temperature and global radiation were $0.75^{\circ} \mathrm{C}$ and $15 \mathrm{~W} \mathrm{~m}^{-2}$ higher in $1997 / 98$ than in $1998 / 99$. This might already explain a large part of the differences. To a certain extent, a heavy precipitation event $(>50 \mathrm{~mm})$ at the beginning of the 1998/99 balance year could have established an early snow cover with high albedo. The more negative mass balances below $2300 \mathrm{~m}$ in 1998/99 might be related to this snowfall event, which reached down to this elevation (see Fig. 2), and the related feedbacks of albedo on the mass balance.

Precipitation and global radiation have been distributed in the model domain with a normalized grid of the mean climatic (period 1971-90) annual precipitation sum (Fig. 3a) and daily grids of mean clear-sky global radiation (Fig. 3b). A closer inspection of both datasets helps to explain the observed pattern of the modeled mass-balance distribution (see next paragraph). With a focus on Vernagtferner, the precipitation increases slightly with elevation (by about $100 \mathrm{~mm}$ ) and also towards the northwesterly margin of the glacier (Fig. 3a). This slight increase is also reflected in the more positive balances modeled in this section of the glacier (Fig. 4a and c). Most parts of the glacier are exposed to high amounts of global radiation during summer, and only the tongue and steep slopes at 'Schwarzwandbereich' and the southernmost accumulation region at 'Brochkogelbereich' show somewhat reduced amounts of potential global radiation (Fig. 3b). This is also reflected in the modeled massbalance distribution, in which the related parts in the accumulation region have somewhat less negative balances than other regions at the same elevation. Hence, the modeled mass-balance distribution agrees best with the observations in regions where the prescribed radiation and precipitation grids have a comparably higher influence on the model results.

\section{Modeled mass-balance pattern}

Clearly, the model was not able to reproduce the positive mass balance in the region around 'Taschachjochbereich' in 1997/98, or the complex pattern of the ELA in 1998/99. In the first case, the wrongly modeled region might have benefited from drifting snow deposited in the lee side of the main ridge (Plattner and others, 2006). In the second case, small-scale undulations of the topography (e.g. local depressions) might have been responsible for the complex ELA structure. Neither of these effects is considered in the model used. With respect to the simplifications made in this model, a more complex parameterization of variables that do depend largely on elevation (e.g. humidity, atmospheric pressure, cloud height) will only shift the absolute values without improving the modeled mass-balance pattern. Moreover, such elevation-dependent variables could not act in opposite directions at the same time, i.e. increasing ablation at the terminus and decreasing it higher up.

On the input data side, it is expected that the consideration of a satellite-derived albedo map from the end of the ablation period would help to improve model performance at the pixel scale (e.g. Machguth and others, 2006a; Paul and others, 2008). The summer of 1998 was quite hot and dry, so albedo could easily go down to 0.2 or even less as a result of the accumulation of dust and soot (Paul and others, 2005). A lowering of the albedo by 0.1 at the terminus could increase melt by about $0.8 \mathrm{mw}$.e., as revealed by a sensitivity study at Findelengletscher, Swiss Alps (Paul and others, 2008). Such an albedo map would also allow an increase in ablation near the terminus and a decrease higher up at the same time.

The overestimation of the mass loss for Kesselwandferner in 1997/98 could also be related to an albedo effect. The model starts with the ice albedo in the entire model domain. For glaciers like Kesselwandferner, which still have a firn reservoir from more positive previous years, this causes more ablation until the first snowfall occurs. The same is true for the summer melt when the snow has disappeared. The model then switches to the 0.3 albedo of ice instead of a 0.4 (or somewhat higher) albedo of firn. The more positive balance in 1998/99 for Hintereisferner is most likely the result of overestimated accumulation at steep slopes. 
At the scale of the entire model domain, the precipitation grid used by Schwarb and others (2001) is certainly the best input dataset available at this high spatial resolution $(2 \mathrm{~km})$ for rugged high-mountain terrain. However, empirical studies have shown that, in some regions, strong corrections are required to obtain realistic glacier mass balances. With regard to the model physics, further improvements are expected from a more detailed consideration of accumulation processes, in particular for glaciers with a locally strong influence of snow redistribution. However, getting this correct over large regions in complex terrain might be a challenge for several more years. The detailed mapping of snow thickness at the end of the winter balance (e.g. Machguth and others, 2006b; Plattner and others, 2006) and the re-evaluation of time series of measured accumulation for Hintereis- and Vernagtferner (Escher-Vetter and others, 2009) might help to achieve this.

\section{Consequences}

Distributed mass-balance models, which are based on the calculation of the energy balance at the glacier surface, allow the consideration of the complex interactions between radiation, temperature and precipitation in rough, highmountain topography (i.e. where glaciers are located). Despite the simplifications made in this study (e.g. fixed cloud height, ice albedo and surface temperature), a realistic pattern of the mass-balance distribution was obtained for most glaciers, in particular for the more positive 1998/99 balance year. This confirms that the applied grid datasets and the modeling approach suitable for quantitative assessments of mass balance over larger regions. It opens the possibility of assessing climate-change impacts on glacier mass balance by direct use of meteorological data obtained from the output of regional climate models that have similar grid-box sizes to the model domain used here (Paul and others, 2006).

In view of the mass-balance distribution, as obtained in the field, improvements to the model applied here are envisaged for: (1) the ablation region - these involve including a satellite-derived albedo map (Paul and others, 2008); and (2) the accumulation region, by incorporating snow redistribution at steep slopes due to avalanches (Machguth and others, 2006a; Gruber, 2007). A promising method for considering the influence of local topographic undulations on snow accumulation has been developed by Purves and others (1998). The same approach might also be useful for a first-order consideration of the snow redistribution by wind in rugged high-mountain topography. However, the required input data for more complex methods of snow redistribution by wind are still quite demanding (e.g. Bernhardt and others, in press) and it is currently unclear whether such approaches will improve the model performance in small regions without degrading it in other regions at the same time. In any case, the manually interpreted massbalance distribution maps will be of great value to develop and test related approaches.

From a more practical point of view, it seems noteworthy that the comparison with lumped parameters, such as mean annual balance, can also give a good agreement in cases of locally strong over- and underestimations when both average out. Although such regions could be identified by comparing mass-balance profiles, these profiles should be based on manually interpreted calculations for discrete elevation bands rather than regression equations. When a glacier basin is composed of several distinct entities (like Vernagtferner), it is possible that certain parts are modeled much better than others. This would only be revealed when maps of the mass-balance distribution are available for comparison. In regions with a small precipitation gradient (here, a $300 \mathrm{~mm}$ increase over $1700 \mathrm{~m}$ of elevation) the pattern of the mass-balance distribution is determined largely by the pattern of mean summer potential global radiation combined with elevation. Accurate calculation of both parameters is thus an important prerequisite for distributed mass-balance modeling over larger regions in rugged terrain.

\section{CONCLUSIONS}

We have applied a distributed energy-/mass-balance model of intermediate complexity to a larger region in the Oetztal Alps using daily values of measured meteorological parameters $(T, R, P)$ from a climate station near Vernagtferner in the balance years $1997 / 98$ and 1998/99. Model results are compared, for the first time, with maps of observed massbalance distribution as interpreted by experts with local knowledge. Although the model reproduces the measured mean mass balance and ELA for Vernagtferner in both years very accurately, it shows larger deviations for the modeled mass-balance gradients and the regional pattern in the more negative balance year 1997/98. In particular, regions where mass balance is influenced by small-scale topographic undulations or redistribution of snow (due to wind or avalanches) exhibit larger deviations to the observed pattern. Further improvements of the model are thus expected from including parameterizations for the related processes. Compared with the position of the snowline, as seen on a satellite image from September 1999, the model performed remarkably well. This suggests that even quite simple parameterizations have a potential for large-area application, in particular for assessing ELA and mass-balance sensitivities of unmeasured glaciers.

\section{ACKNOWLEDGEMENTS}

This study was partly funded by the Swiss National Science Foundation (grant 21-105214/1). The funding from the Academy Research Programme III.B.1 of the Federal Republic of Germany and the State of Bavaria for H.E.-V. is gratefully acknowledged. Two anonymous reviewers helped to improve the paper considerably.

\section{REFERENCES}

Arnold, N.S., I.C. Willis, M.J. Sharp, K.S. Richards and W.J. Lawson. 1996. A distributed surface energy-balance model for a small valley glacier. I. Development and testing for Haut Glacier d'Arolla, Valais, Switzerland. J. Glaciol., 42(140), 77-89.

Arnold, N.S., W.G. Rees, A.J. Hodson and J. Kohler. 2006. Topographic controls on the surface energy balance of a high Arctic valley glacier. J. Geophys. Res., 111(F2), F02011. (10.1029/2005JF000426.)

Bernhardt, M., G. Zängl, G.E. Liston, U. Strasser and W. Mauser. In press. Using wind fields from a high resolution atmospheric model for simulating snow dynamics in mountainous terrain. Hydrol. Process..

Brock, B.W., I.C. Willis, M.J. Sharp and N.S. Arnold. 2000. Modelling seasonal and spatial variations in the surface energy 
balance of Haut Glacier d'Arolla, Switzerland. Ann. Glaciol., 31, 53-62.

Carturan, L. and R. Seppi. 2007. Recent mass balance results and morphological evolution of Careser Glacier (Central Alps). Geogr. Fís. Din. Quat., 30(1), 33-42.

Escher-Vetter, H. 1985. Energy balance calculations from five years' meteorological records at Vernagtferner, Oetztal Alps. Z. Gletscherkd. Glazialgeol., 21(1-2), 397-402.

Escher-Vetter, H. 2000. Modelling meltwater production with a distributed energy balance method and runoff using a linear reservoir approach: results from Vernagtferner, Oetztal Alps, for the ablation seasons 1992 to 1995. Z. Gletscherkd. Glazialgeol., 36(1-2), 119-150.

Escher-Vetter, H., M. Kuhn and M. Weber. 2009. Analysis of the accumulation amounts of three neighbouring Oetztal glaciers based on measured and modelled mass-balance data. Ann. Glaciol., 50, 87-95.

European Centre for Medium-Range Weather Forecasts (ECMWF) 2004. The integrated forecast system (IFS). Documentation CY28r1. Reading, European Centre for Medium-Range Weather Forecasts.

Farr, T.G. and 17 others. 2007. The Shuttle Radar Topography Mission. Rev. Geophys., 45(2), RG2004. (10.1029/ 2005RG000183.)

Frei, C. and C. Schär. 1998. A precipitation climatology of the Alps from high-resolution rain-gauge observations. Int. J. Climatol., 18(8), 873-900.

Gerbaux, M., C. Genthon, P. Etchevers, C. Vincent and J.P. Dedieu. 2005. Surface mass balance of glaciers in the French Alps: distributed modeling and sensitivity to climate change. l. Glaciol., 51(175), 561-572.

Greuell, W. and J. Oerlemans. 1986. Sensitivity studies with a mass-balance model including temperature profile calculations inside the glacier. Z. Gletscherkd. Glazialgeol., 22(2), 101-124.

Gruber, S. 2007. A mass-conserving fast algorithm to parameterize gravitational transport and deposition using digital elevation models. Water Resour. Res., 43(6), W06412. (10.1029/ 2006WR004868.)

Heggem, E.S.F., B. Etzelmüller and I. Berthling. 2001. Topographic radiation balance models: sensitivity and application in periglacial geomorphology. Nor. Geogr. Tidsskr., 55(4), 203-211.

Hock, R. 2005. Glacier melt: a review on processes and their modelling. Progr. Phys. Geogr., 29(3), 362-391.

Hock, R. and B. Holmgren. 2005. A distributed surface energybalance model for complex topography and its application to Storglaciären, Sweden. J. Glaciol., 51(172), 25-36.

Hock, R. and H. Jensen. 1999. Application of kriging interpolation for glacier mass balance computations. Geogr. Ann., 81A(4), 611-619.

Huss, M., A. Bauder, M. Funk and R. Hock. 2008. Determination of the seasonal mass balance of four Alpine glaciers since 1865. J. Geophys. Res., 113(F1), F01015. (10.1029/2007JF000803.)

Kaser, G., A. Fountain and P. Jansson. 2003. A manual for monitoring the mass balance of mountain glaciers. Paris, UNESCO. (IHP-VI Technical Documents in Hydrology 59.)

Klok, E.J. and J. Oerlemans. 2002. Model study of the spatial distribution of the energy and mass balance of Morteratschgletscher, Switzerland. J. Glaciol., 48(163), 505-518.

Kommission für Glaziologie. 2001. Orthophotokarte Vernagtferner 1999. Munich, Technical University Munich. Bavarian Academy of Sciences and Humanities/Institute for Photogrammetry and Carthography.

Kuhn, M. 1995. The mass balance of very small glaciers. Z. Gletscherkd. Glazialgeol., 31(1-2), 171-179.

Kuhn, M., G. Markl, G. Kaser, U. Nickus, F. Obleitner and H. Schneider. 1985. Fluctuations of climate and mass balance: different responses of two adjacent glaciers. Z. Gletscherkd. Glazialgeol., 21, 409-416.

Machguth, H., F. Paul, M. Hoelzle and W. Haeberli. 2006a. Distributed glacier mass-balance modelling as an important component of modern multi-level glacier monitoring. Ann. Glaciol., 43, 335-343.

Machguth, H., O. Eisen, F. Paul and M. Hoelzle. 2006b. Strong spatial variability of snow accumulation observed with helicopter-borne GPR on two adjacent Alpine glaciers. Geophys. Res. Lett., 33(13), L13503. (10.1029/2006GL026576.)

Mittaz, C., M. Imhof, M. Hoelzle and W. Haeberli. 2002. Snowmelt evolution mapping using an energy balance approach over an Alpine terrain. Arct. Antarct. Alp. Res., 34(3), 274-281.

Oerlemans, J. 1991. A model for the surface balance of ice masses: Part 1. Alpine glaciers. Z. Gletscherkd. Glazialgeol., 27/28, $3-83$.

Oerlemans, J. 1992. Climate sensitivity of glaciers in southern Norway: application of an energy-balance model to Nigardsbreen, Hellstugubreen and Alfotbreen. J. Glaciol., 38(129), 223-232.

Oerlemans, J. 2001. Glaciers and climate change. Lisse, etc., A.A. Balkema.

Paul, F. 2002. Combined technologies allow rapid analysis of glacier changes. Eos, 83(23), 253, 260-261.

Paul, F., H. Machguth and A. Kääb. 2005. On the impact of glacier albedo under conditions of extreme glacier melt: the summer of 2003 in the Alps. EARSeL eProc., 4(2), 139-149.

Paul, F., S. Kotlarski and M. Hoelzle. 2006. Coupling of a distributed glacier mass balance model to the regional climate model REMO: down-scaling strategy and first results. Geophys. Res. Abstr., 8, 09019. (1607-7962/gra/EGU06-A-09019.)

Paul, F., H. Machguth, M. Hoelzle, N. Salzmann and W. Haeberli. 2008. Alpine-wide distributed glacier mass-balance modelling: a tool for assessing future glacier change? In Orlove, B., E. Wiegandt and B.H. Luckman, eds. Darkening peaks: glacier retreat, science, and society. Berkeley, CA, University of California Press, 111-125.

Paul, F., A. Kääb and W. Haeberli. 2007. Recent glacier changes in the Alps observed from satellite: consequences for future monitoring strategies. Global Planet. Change, 56(1-2), 111-122.

Plattner, C., L.N. Braun and A. Brenning. 2006. Spatial variability of snow accumulation on Vernagtferner, Austrian Alps, in winter 2003/04. Z. Gletscherkd. Glazialgeol., 39, 43-57.

Purves, R.S., J.S. Barton, W.A. Mackaness and D.E. Sugden. 1998. The development of a rule-based spatial model of wind transport and deposition of snow. Ann. Glaciol., 26, 197-202.

Reijmer, C.H. and R. Hock. 2008. Internal accumulation on Storglaciären, Sweden, in a multi-layer snow model coupled to a distributed energy- and mass-balance model. J. Glaciol., 54(184), 61-72.

Reinwarth, O. and H. Escher-Vetter. 1999. Mass balance of Vernagtferner, Austria, from 1964/65 to 1996/97: results for three sections and the entire glacier. Geogr. Ann., 81A(4), 743-751.

Schuler, T.V. and 6 others. 2005. Distributed mass-balance and climate sensitivity modelling of Engabreen, Norway. Ann. Glaciol., 42, 395-401.

Schwarb, M., C. Daly, C. Frei and C. Schär. 2001. Mean annual precipitation throughout the European Alps, 1971-1990. In Hydrologic atlas of Switzerland. Bern, National Hydrologic Service, plates 2.6-2.7.

Wilson, J.P. and J.C. Gallant, eds. 2000. Terrain analysis: principles and applications. New York, Wiley.

World Glacier Monitoring Service (WGMS). 2001. Glacier Mass Balance Bulletin No. 6 (1997-1998), ed. Haeberli, W., R. Frauenfelder and M. Hoelzle. IAHS (ICSI)/UNEP/UNESCO/ WMO, World Glacier Monitoring Service, Zürich. 